
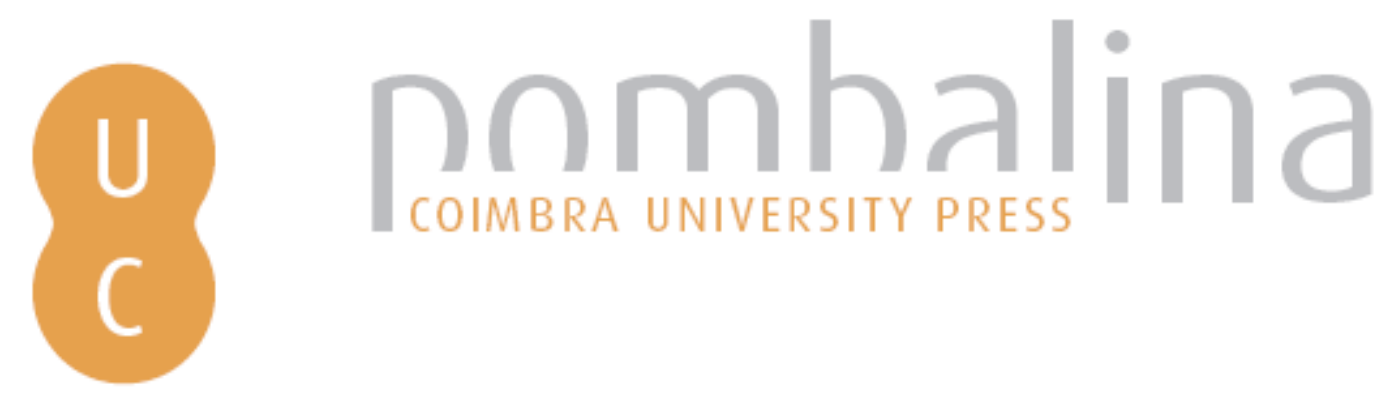

\title{
Giant hydatid cyst: an unsuspected possible cause of sudden death
}

$\begin{array}{ll}\text { Autor(es): } & \text { Nikolic, D.; Gouveia, R. Henriques de; Pedrosa, F.; Ribeiro, I. Pinto; }\end{array}$

Publicado por: Imprensa da Universidade de Coimbra

URL

persistente: URI:http://hdl.handle.net/10316.2/31718

DOI: $\quad$ DOI:http://dx.doi.org/10.14195/978-989-26-0173-1_81

Accessed : $\quad$ 26-Apr-2023 09:28:51

A navegação consulta e descarregamento dos títulos inseridos nas Bibliotecas Digitais UC Digitalis, UC Pombalina e UC Impactum, pressupõem a aceitação plena e sem reservas dos Termos e Condições de Uso destas Bibliotecas Digitais, disponíveis em https://digitalis.uc.pt/pt-pt/termos.

Conforme exposto nos referidos Termos e Condições de Uso, o descarregamento de títulos de acesso restrito requer uma licença válida de autorização devendo o utilizador aceder ao(s) documento(s) a partir de um endereço de IP da instituição detentora da supramencionada licença.

Ao utilizador é apenas permitido o descarregamento para uso pessoal, pelo que o emprego do(s) título(s) descarregado(s) para outro fim, designadamente comercial, carece de autorização do respetivo autor ou editor da obra.

Na medida em que todas as obras da UC Digitalis se encontram protegidas pelo Código do Direito de Autor e Direitos Conexos e demais legislação aplicável, toda a cópia, parcial ou total, deste documento, nos casos em que é legalmente admitida, deverá conter ou fazer-se acompanhar por este aviso.

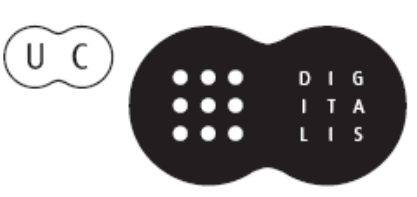




\section{Duarte Nuno Vieira Anthony Busuttil \\ Denis Cusack • Philip Beth}
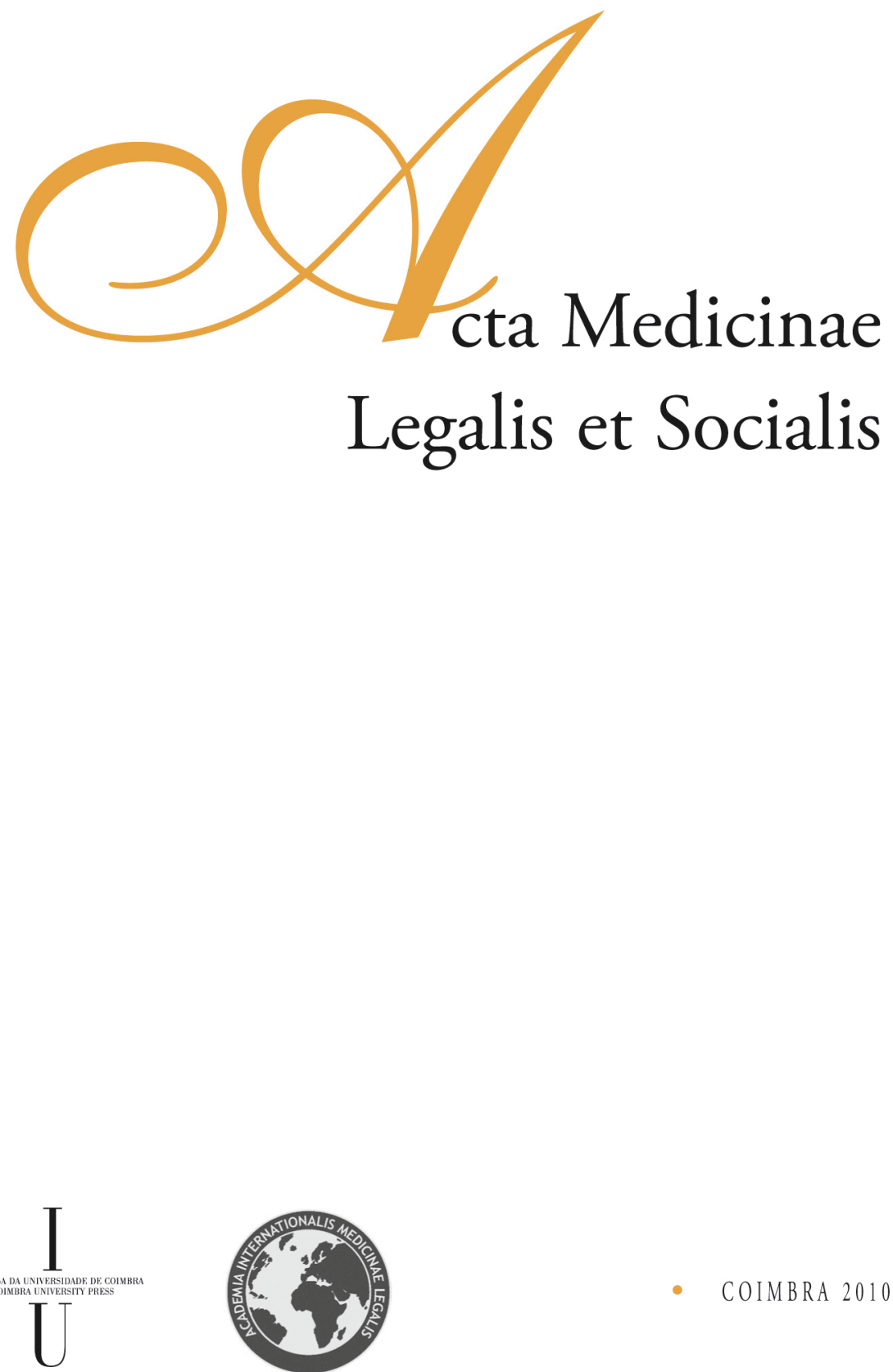


\author{
D. Nikolić, R. Henriques de Gouveia, F. Pedrosa, I. Pinto Ribeiro, F. Costa \\ Santos, J. Costa Santos \\ Forensic Pathology Department, South Branch of the National Institute of Legal Medicine, Lisbon, \\ Portugal
}

\title{
GIANT HYDATID CYST: AN UNSUSPECTED POSSIBLE CAUSE OF SUDDEN DEATH
}

\section{Introduction}

Hydatid cyst (Echinococcosis multilocularis) is an uncommon human parasitic infestation in the so-called developed countries, seen most usually in Mediterranean areas, Australia and South America where it is endemic. ${ }^{1,2,4,5}$ Signs and symptoms vary, depending on the anatomical location and dimension of the cyst. ${ }^{2}$ Usually it is located in the liver $(55-75 \%)^{2,3,5,6}$ and the clinical diagnosis requires a high level of suspicion. ${ }^{3,6,7}$

\section{Material and methods}

The present case refers to a Caucasian 93-year old female with a non-natural cause of death, due to severe craneo-encephalic lesions after an accidental fall. A postmortem examination was performed.

\section{Results}

The autopsy showed blunt force trauma to the right side of the head with cranial fractures and brain contusion. Unexpectedly, an hepatic mass was found (Figure 1). It occupied most of the abdominal cavity and extended to the pelvic area. Macroscopically, it weighed $9500 \mathrm{~g}$, measuring $33 \mathrm{~cm}$ of diameter (Figure 2). The cut surface was cystic and contained a yellowish amorphous material with multiple vesicles resembling "daughter cysts" (Figure 3).

Microscopic examination disclosed the presence of a surrounding fibrous capsule (Figure 4), an outer laminated and an inner germinative membranes (Figure 5), as well as scolices amidst necrotic material and neutrophilic infiltrates (Figure 6), thus confirming the macroscopic hypothesis of hydatid cyst of the liver. ${ }^{8 *}$

\footnotetext{
${ }^{*} \mathrm{FC}=$ fibrous capsule, $\mathrm{LM}=$ laminated membrane, $\mathrm{GM}=$ germinative membrane, $\mathrm{S}=$ scolices.
} 


\section{Discussion and conclusions}

Hidatid disease is a parasitic infection most frequently caused by the larval form of the tapeworm E. granulosus, which uses the dog as the definitive host. ${ }^{9,10}$

After ingestion, the larvae go through the duodenal wall to the portal blood system and into the liver, where they are found in about $60 \%$ of cases.

Some of them may escape hepatic filtration and continue to the pulmonary circulation. A small percentage may reach the systemic circulation, resulting in infection and cyst formation in any organ. 9,10

There may be symptoms of a feeling of pressure, but generally the cyst does not cause any clinical symptoms for a long time. ${ }^{2}$ The cysts increase slowly in size, commonly reaching a sizeable mass over several years.

The fluid inside the cyst has highly antigenic properties, which may result in anaphilactoid reactions due to leakage either into a vessel or body cavity.

In Portugal the incidence of hydatid disease is very low (79 cases between 2000 and 2004), probably due to underreporting of the disease. It is in Alentejo (agricultural region) that the highest incidence can be found $-80 \%$.

This case highlights the importance of histopathological exams even in the context of violent deaths.

It's relevance, apart from the gigantic dimensions (the 2 nd largest9 in the literature, to our knowledge), lies in the possibility of spontaneous or traumatic rupture - with legal implications, consequently causing anaphylactic shock, which may lead to sudden death.

\section{References}

${ }^{1}$ PAKIS I, AKYILDIZ EU, KARAYEL F, TURAN AA, SENEL B, OZBAY M, CETIN G, Sudden Death due to an Unrecognized Cardiac Hydatid Cyst: three medico legal autopsy cases, J. Forensic Sci., 2006; 51 (2): 400-402.

${ }^{2}$ KOK AN, YURTMAN T, AYDIN NE, Sudden death due to ruptured hydatid cyst of the liver, J. Forensic Sci., 1993; 38 (4): 978-980.

${ }^{3}$ MELO M, MENDONÇA T, RODRIGUES R, ROMÃO A, SOARES C, VARELA J, CHIADO A, DIAS J, LOPES T, Quisto Hidático Renal, Esplénico e Torácico: A propósito de um caso clínico, Acta Urológica, 2007, 24; 2:55-134.

${ }^{4}$ GONÇALVES AP, LUÍS F, BENTO A, SILVA JM, Mediastinal Hydatid Cyst. Reflections on a case study, Revista Portuguesa de Pneumologia, Vol. XIII no 4, 2007.

5 SAFIOLEAS MC, MISIAKOS EP, KOUVARAKI M, STAMATAKOS MK, MANTI CP, FELEKOURAS ES, Hydatid Disease of the Liver A Continuing Surgical Problem, Arch. Surg. Vol. 141, Nov 2006, pp. 1101-1108.

${ }^{6}$ OZTURK G, AYDINLI B, YILDIRGAN MI, BASOGLU M, ATAMANALP SS, POLAT KY, ALPER F, GUVENDI B, AKCAY MN, OREN D, Posttraumatic Free Intraperitoneal Rupture of Liver Cystic Echinoccocosis: A case series and review of literature, Am. J. Surgery 194, 2007, pp. 313-316.

7 SOZUER EM, OK E, ARSLAN M, The Perforation Problem In Hydatid Disease, Am. J. Trop. Med. Hyg., 66(5), 2002, pp. 575-577. 
${ }^{7}$ COTRAN RS, KUMAR V, ROBBINS SI, Robbin's pathologic basis of disease, Philadelphia PA, Saunders, 1989.

${ }^{8}$ JUAN ROSAI, Rosai and Ackerman's Surgical Pathology, Mosby, 2004.

${ }^{10}$ MALAMOU-MITSI V., PAPPA L., VOUGIOUKLAKIS T., PESCHOS D., KAZAKOS N., GREKAS G., SIDERIS D., AGNANTIS N., Sudden Death Due to an Unrecognized Cradiac Hydatid Cyst.

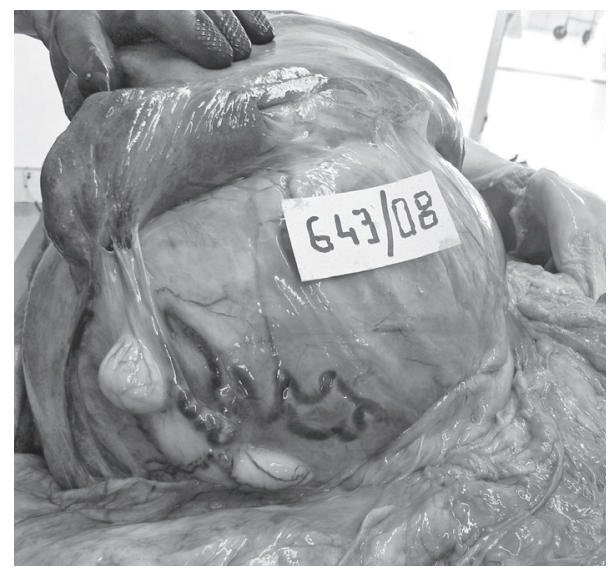

Figure 1 - Hepatic mass found at autopsy

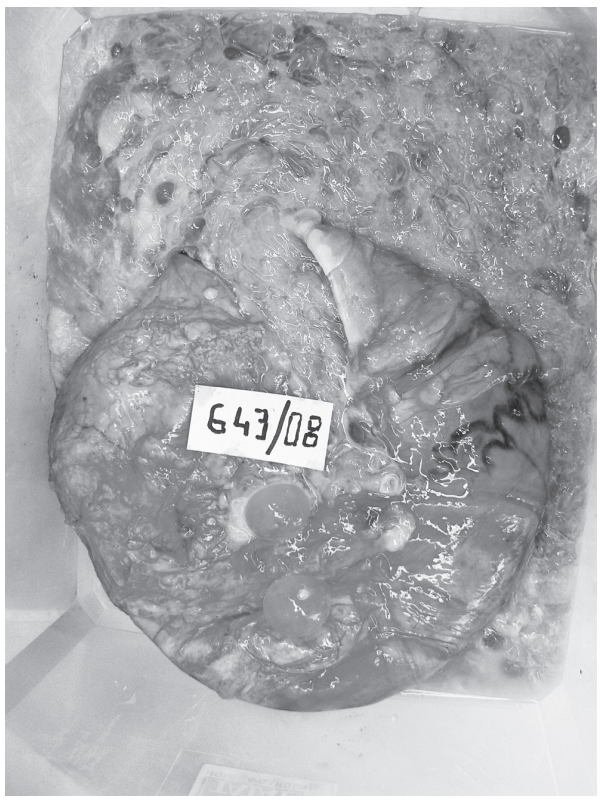

Figure 3 - Content of hydatid cyst

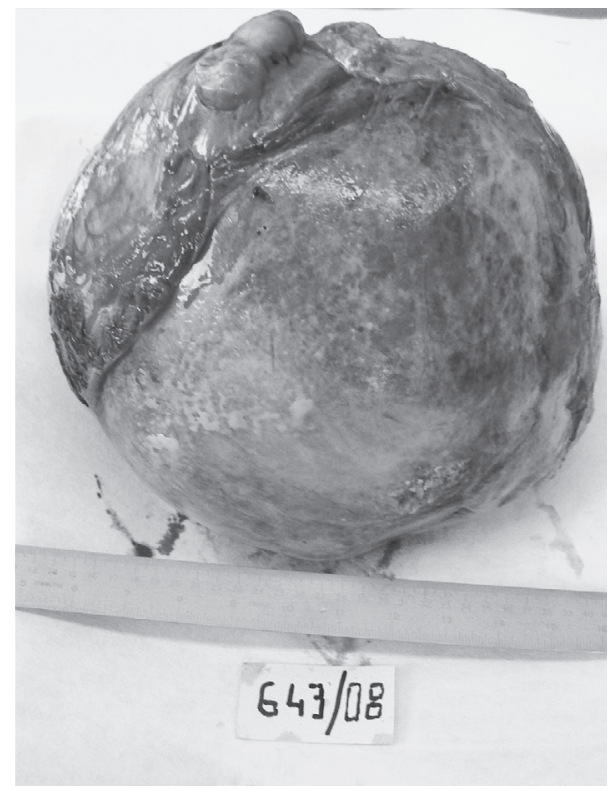

Figure 2 - Hepatic hydatid cyst

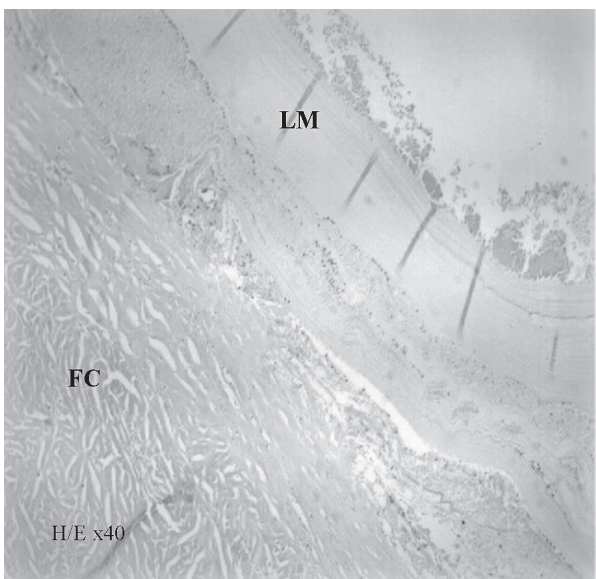

Figure 4 - Microscopic aspect of fibrous capsule and laminated membrane 


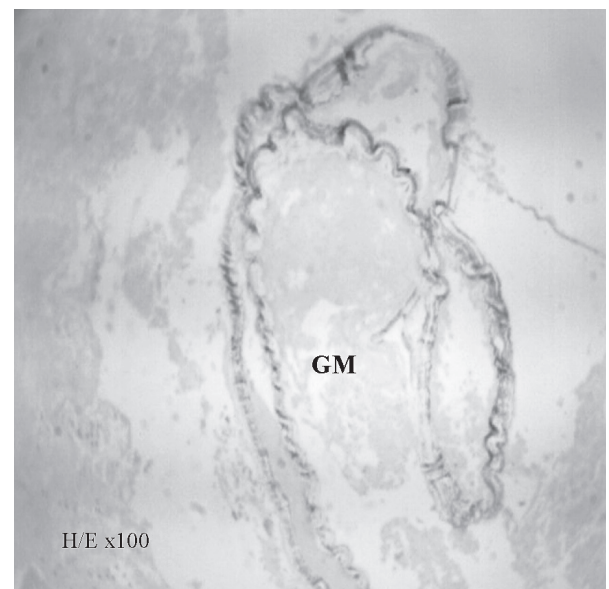

Figure 5 - Microscopic aspect of germinative membrane

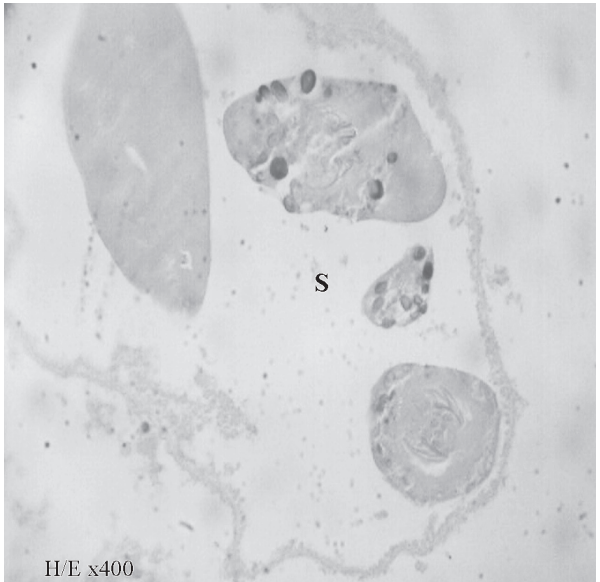

Figure 6-Microscopic aspect of $E$. multilocularis scolices 